\title{
GOOD CORPORATE GOVERNANCE (GCG) DALAM PERBANKAN SYARIAH
}

\author{
ABDUL HARIS ROMDHONI \\ STIE AAS Surakarta \\ Email : harisromdhoni27@yahoo.com
}

\begin{abstract}
This study is about good corporate governance is an increasingly crowded studied both in the acadimician and practiciant. With good corporate governance are applied consistently positive for the Islamic banks, due to the good corporate governance include things that are in line with Islamic law such as transparency, independence, accountability and responsibility.

Therefore good corporate governance will create a culture of superior companies, so that with the superior culture of what the objectives of the company will be more easily achieved. In addition, a culture of excellence will form a dynamic working atmosphere and professional.

Good corporate governance will also strengthen the system so that the function of leadership and organization will establish a value. If it will continue on an ongoing basis it will make a positive contribution that benefits the company, or Islamic banking. Trust will also be obtained both from internal and external company or Islamic banks.
\end{abstract}

\section{LATAR BELAKANG}

Pengalaman adalah guru yang terbaik, tampaknya pepatah bijak tersebut benar-benar dipegang oleh Bank Indonesia. Bagaimana tidak, belajar dari pengalaman krisis moneter tahun 1998 yang melumpuhkan sendi-sendi perekonomian nasional yang pada proses berikutnya membawa krisis multidimensi yang berkepanjangan. Pada krisis tahun 1998 pula tercatat 16 bank terpaksa dilikuidasi oleh Pemerintah. Nilai tukar rupiah terhadap US dollar menembus angka Rp. 16.000, PHK dan pengangguran terjadi dimana-mana serta angka kemiskinan meningkat akibat daya beli dan pendapatan masyarakat menurun.
Krisis serupa kembali mengancam perbankan nasional sekitar pada tahun 2007 akibat kondisi makro ekonomi yang tidak kondusif seperti naiknya suku bunga perbankan, melemahnya nilai tukar rupiah terhadap dollar Amerika, tingginya angka inflasi. Keadaan tersebut tidak lepas pengaruhnya dari krisis yang terjadi di Amerika Serikat yang kemudian berpengaruh di sebagian besar di dunia. Di Indonesia walaupun terkena imbas dari krisis tersebut namun pertumbuhan ekonominya masih mengalami pertumbuhan yang positif, sehingga secara ekonomi cukup tahan terhadap goncangan krisis ekonomi dunia.

Berangkat dari krisis tersebut Bank Indonesia (BI) berusaha harus mengantisipasi 
supaya hal yang sama tidak terulang kembali. BI sebagai pengawas perbankan nasional atau bankers of bank mengambil kebijakan antisipatif yang salah satunya adalah untuk menerapkan kebijakan good corporate governance (GCG). GCG adalah keniscayaan yang perlu diambil mengingat semakin maraknya atau pendirian bank-bank yang ada di Indonesia, baik perbankan konvesional lebih khusus lagi adalah perbankan syariah. Menurut Biro Riset Infobank pertumbuhan perbankan syariah cukup signifikan,seperti asset bank syariah tumbuh 47,69 \% menjadi Rp.18,03 triliun (per Agustus 2005) dari 12,21 triliun (per Agustus 2004). Dana pihak ketiga mengalami pertumbuhan 44,41\% menjadi 13,5 triliun (per Agustus 2005) dari 9,35 triliun (per Agustus 2004). Pembiayaan syariah mengalami peningkatan sebesar 50,79\% menjadi 14,39 triliun (per Agustus 2005) dari

\section{PEMBAHASAN}

\section{Forum for Corporate Governance (FCG) dalam publikasi yang pertamanya mempergunakan definisi Cadbury Committee, yaitu: "seperangkat peraturan yang mengatur hubungan antara pemegang saham, pengurus (pengelola) perusahaan, pihak kreditur, pemerintah, karyawan serta para pemegang kepentingan intern dan ekstern lainnya yang berkaitan dengan hak-hak dan kewajiban mereka, atau dengan kata lain suatu sistem yang mengatur dan mengendalikan perusahaan" (Retno, 2012).}

Corporate governance dibangun dari dua teori utama yaitu stewardship theory dan agency theory (Chinn,2000; Shaw,2003 dalam Kaihatu, 2006). Stewardship theory dibangun di atas asumsi filosofis mengenai sifat manusia yakni
9,54 triliun (per Agustus 2004). Selama periode yang sama bank syariah mampu membukukan laba tahun berjalan sebesar Rp. 178 milliar atau mengalami peningkatan 56,14\% dari tahun sebelumnya (Endraswati, 2007).

Dengan diterapkan good corporate governance (GCG) oleh Pemerintah ataupun Bank Indonesia (BI) diharapkan akan tercipta iklim usaha yang kondusif, sehat, efisien dan transparan. Maka dari itu BI mengeluarkan Peraturan Bank Indonesia Nomor 11/33/PBI/2009 tentang pelaksanaan good corporate governance (GCG) bagi Bank Umum Syariah dan Unit Usaha Syariah. Peraturan tersebut diberlakukan sejak 1 Januari 2010 sekaligus menggantikan Peraturan Bank Indonesia No.8/4/PBI/2006.

bahwa manusia pada hakekatnya dapat dipercaya, mampu bertindak dengan penuh tanggung jawab, memiliki integritas dan kejujuran terhadap pihak lain. Good corporate governance (GCG) secara definitif merupakan sistem yang mengatur dan mengendalikan perusahaan yang menciptakan nilai tambah (value added) untuk semua stakeholder (Monks,2003 dalam Kaihatu, 2006). Ada dua hal yang ditekankan dalam konsep ini, pertama, pentingnya hak pemegang saham untuk memperoleh informasi dengan benar dan tepat pada waktunya dan, kedua, kewajiban perusahaan untuk melakukan pengungkapan (disclosure) secara akurat, tepat waktu, transparan terhadap semua informasi kinerja perusahaan, kepemilikan, dan stakeholder.

Sementara itu, agency theory yang dikembangkan oleh Michael Johnson, 
memandang bahwa manajemen perusahaan sebagai "agents" bagi para pemegang saham, akan bertindak dengan penuh kesadaran bagi kepentingannya sendiri, bukan sebagai pihak yang arif dan bijaksana serta adil terhadap pemegang saham. Sedangkan menurut Brigham \& Houston (2006: 26-31) para manajer diberi kekuasaaan oleh pemilik perusahaan, yaitu pemegang saham, untuk membuat keputusan, dimana hal ini menciptakan potensi konflik kepentingan yang dikenal sebagai teori keagenan (agency theory). Hubungan keagenan (agency relationship) terjadi ketika satu atau lebih individu, yang disebut sebagai prinsipal menyewa individu atau organisasi lain, yang disebut sebagai agen, untuk melakukan sejumlah jasa dan mendelegasikan kewenangan untuk membuat keputusan kepada agen tersebut.

Ada empat komponen utama yang diperlukan dalam konsep good corporate governance, (Kaen 2003; Shaw, 2003 dalam Kaihatu, 2006) yaitu fairness, transparency, accountability, dan responsibility. Keempat komponen tersebut penting karena penerapan prinsip good corporate governance secara konsisten terbukti dapat meningkatkan kualitas laporan keuangan dan juga dapat menjadi penghambat aktivitas rekayasa kinerja yang mengakibatkan laporan keuangan tidak menggambarkan nilai fundamental perusahaan.

Konsep good corporate governance baru popular di Asia. Konsep ini relatif berkembang sejak tahun 1990-an. Konsep good corporate governance baru dikenal di Inggris pada tahun 1992. Negara-negara maju yang tergabung dalam kelompok OECD (kelompok Negaranegara maju di Eropa Barat dan Amerika Utara) mempraktikkan pada tahun 1999 (Kaihatu, 2006)
Berdasarkan survei yang dilakukan Bank Dunia pada tahun 2007 menunjukkan bahwa iklim bisnis di Indonesia mengalami perbaikan 4 level yaitu peringkat 135 dari 175 negara. Hal itu dapat dilihat dari misalnya, pemberian ijin usaha baru yang lebih cepat dan lebih mudah dalam persyaratan usaha. Dengan semakin kondusif iklim usaha maka investasi baik domestik maupun asing akan semakin deras mengalir ke dalam negeri.

Penerapan GCG sangat dipengaruhi oleh budaya organisasi perusahaan itu sendiri. Menurut Robins (2001) budaya organisasi adalah suatu persepsi bersama yang dianut oleh anggota-anggota organisasi atau suatu system dari makna bersama. Sedangkan GCG adalah langkah awal untuk membentuk budaya organisasi atau perusahaan yang diinginkan yaitu budaya unggul.

Good corporate governance (GCG) secara definitif merupakan sistem yang mengatur dan mengendalikan perusahaan untuk menciptakan nilai tambah (value added) untuk semua stakeholder. Dua hal yang ditekankan dalam konsep ini adalah yang pertama, pentingnya hak pemegang saham untuk memperoleh informasi dengan benar dan tepat pada waktunya, yang kedua, kewajiban perusahaan untuk melakukan pengungkapan secara akurat, tepat waktu dan transparan terhadap informasi kinerja perusahaan, kepemilikan dan stakeholder (Moeljono, 2005).

Sedangkan penerapan prinsip-prinsip good corporate governance meliputi hal-hal sebagai berikut :

1. Transparansi yaitu keterbukaan dalam melaksanakan proses pengambilan keputusan dan keterbukaan dalam 
mengungkapkan informasi material yang relevan mengenai perusahaan.

2. Kemandirian yaitu keadaan di mana perusahaan dikelola secara professional tanpa benturan kepentingan dan pengaruh atau tekanan dari pihak manapun yang tidak sesuai dengan peraturan perundangundangan dan prinsip-prinsip korporasi yang sehat.

3. Akuntabilitas yaitu kejelasan fungsi, pelaksanaan dan pertanggungjawaban organ sehingga pengelolaan perusahaan terlaksana secara efektif.

4. Pertangungjawaban yaitu kesesuaian dalam pengelolaan perusahaan terhadap peraturan perundang-undangan dan prinsip-prinsip korporasi yang sehat.

5. Kewajaran yaitu kesesuaian di dalam pengelolaan perusahaan terhadap peraturan perundang-undangan dan prinsip-prinsip korporasi yang sehat.

Sedangkan isi laporan pelaksanaan GCG bagi bank umum syariah (BUS) dan unit usaha syariah (UUS) adalah meliputi hal-hal sebagai berikut :

1. Kesimpulan umum dari hasil penilaian self assessment atas pelaksanaan GCG.

2. Kepemilikan saham anggota Dewan Komisaris, hubungan keuangan dan hubungan keluarga anggota Dewan Komisaris dengan anggota Dewan Komisaris lain, anggota direksi dan/ atau pemegang saham pengendali BUS serta jabatan rangkap pada perusahaan atau lembaga lain.

3. Kepemilikan saham anggota Direksi serta hubungan keuangan dan hubungan keluarga anggota Dewan Komisaris dengan anggota Dewan Komisaris lain, anggota Direksi lain dan/ atau pemegang saham pengendali BUS.

4. Rangkap jabatan sebagai anggota Dewan Pengawas Syariah (DPS) pada lembaga keuangan syariah lainnya.

5. Daftar konsultan, penasehat atau yang dipersamakan dengan itu yang digunakan oleh BUS.

6. Kebijakan renumerasi dan fasilitas lain bagi Dewan Komisaris, Direksi dan Dewan Pengawas Syariah.

7. Rasio gaji tertinggi dan gaji terendah.

8. Frekuensi rapat Dewan Komisaris.

9. Frekuensi rapat Dewan Pengawas Syariah.

10. Jumlah penyimpangan yang terjadi dan upaya penyelesaian oleh BUS.

11. Jumlah permasalahan hukum perdata maupun pidana dan upaya penyelesaian oleh BUS.

12. Transaksi yang mengandung benturan kepentingan.

13. Buy back shares dan/ atau buy back obligasi BUS.

14. Penyaluran dana untuk kegiatan sosial baik jumlaj maupun pihak penerima dana.

15. Pendapatan non halal dan penggunaannya (Peraturan Bank Indonesia No. 11/33/PBI/2009).

Sedangkan Bank Syariah atau Bank Islam sendiri adalah merupakan lembaga keuangan yang usaha pokoknya memberikan pembiayaan dan jasa-jasa lainnya dalam lalu lintas pembayaran serta peredaran uang yang pengoperasiannya disesuaikan dengan prinsipprinsip syariat Islam. Sebagai bank syariah tentu harus ada perbedaan secara idiil maupun operasional dengan bank konvensional yang masih lekat dan dekat praktek riba atau sistem 
bunga. Bank syariah dalam operasionalnya supaya tidak terjebak dalam dengan sistem bunga maka, Islam menawarkan pilihan solusi yang berlandaskan prinsip-prinsip syariah atau dalam muamalah dalam Islam (prinsip bagi hasil).

Hanya saja untuk menerapkan prinsipprinsip yang diidealkan masih butuh perjuangan panjang, apalagi perbankan dengan sistem bunga sudah lama diterapkan dan sudah akrab serta masyarakat menganggap bahwa sistem bunga jauh lebih murah dan mudah. Namun sejalan dengan sejarah dan perkembangannnya bank syariah telah membuktikan bahwa sistem syariahlah yang mampu bertahan dari terpaan krisis moneter pada tahun 1998 dan tahun 2007 lalu. Dengan adanya bukti-bukti tersebut maka sekarang banyak berdiri bank-bank syariah maupun lembaga keuangan non-bank seperti baitul mal wattanwil (BMT), koperasi syariah. Bahkan tidak sedikit bank konvensional baik milik pemerintah maupun swasta yang mendirikan unit usaha syariah (UUS).

Secara khusus peranan bank syariah secara nyata dapat terwujud dalam aspek-aspek sebagai berikut :

1. Menjadi perekat nasionalisme baru artinya bank syariah dapat menjadi fasilitator aktif bagi terbentuknya jaringan usaha ekonomi kerakyatan. Di samping itu bank syariah perlu mencontoh keberhasilan Sarekat Dagang Islam (SDI) kemudian ditarik keberhasilannya untuk masa kini (nasionalis, demokratis, religious dan ekonomis).

2. Memberdayakan ekonomi umat dan beroperasi secara transparan. Artinya pengelolaan bank syariah harus didasarkan pada visi ekonomi kerakyatan dan upaya ini terwujud jika ada mekanisme operasi yang transparan.

3. Memberikan return yang lebih baik. Artinya, investasi di bank syariah tidak memberikan janji yang pasti mengenai return (keuntungan) yang diberikan kepada investor. Oleh karena itu, bank syariah harus mampu memberikan return yang lebih baik daripada yang diberikan oleh bank konvensional. Di samping itu, nasabah pembiayaan akan memberikan bagi hasil sesuai dengan keuntungan yang diperoleh. Oleh karena itu, pengusaha harus memberikan keuntungan yang tinggi kepada bank syariah.

4. Mendorong penurunan spekulasi di pasar keuangan. Artinya, bank syari'ah mendorong terjadinya transaksi produktif dari dana masyarakat. Dengan demikian, spekulasi dapat ditekan.

5. Mendorong pemerataan pendapatan. Artinya bank syari'ah bukan hanya mengumpulkan dana pihak ketiga, namun dapat mengumpulkan dana Zakat, Infaq dan Shadaqah (ZIS). Dana ZIS dapat disalurkan melalui pembiayaan Qardul Hasan, sehingga dapat mendorong pertumbuhan ekonomi. Pada akhirnya terjadi pemerataan ekonomi.

6. Peningkatan efisiensi mobilisasi dana. Artinya, adanya produk al-mudharabah al muqayyadah, berarti terjadi kebebasan bank untuk melakukan investasi atas dana yang diserahkan oleh investor, maka bank syari'ah sebagai financial arranger, bank memperoleh komisi atau bagi hasil, bukan spread bunga. 
7. Uswah hasanah implementasi moral dalam penyelenggaraan usaha bank.

8. Salah satu sebab terjadinya krisis adalah adanya Korupsi, Kolusi Nepotisme $(\mathrm{KKN})$.

Sedangkan pada sisi good corporate governance ada beberapa faktor yang menjadi pemicu untuk perbaikan governance. Pertama, dorongan regulasi yaitu dengan adanya penegakkan hukum (law inforcement) yang baik dan memadai untuk menciptakan iklim usaha yang sehat, serta didukung dengan penerapannya secara konsisten,termasuk pemberian sanksi bagi yang melanggar. Maka akan ada dorongan regulasi (regulation driven) yang memaksa semua pihak untuk mematuhi. Kedua, dorongan pasar di sini lebih menekankan pada kinerja pasar, di mana masyarakat dan para investor menilai sebuah perusahaan dari kinerja (performance), jika ada dorongan pasar (market driven) maka akan terbangun sistem pasar yang secara otomatis akan memberikan penghargaan yang lebih tinggi kepada perusahaan yang terbukti menerapkan GCG dan memiliki kinerja yang baik. Hal sama akan terjadi sebaliknya pada perusahaan yang tidak menerapkan GCG dan memiliki kinerja yang tidak baik, maka akan sendirinya akan "menghukum" perusahaan tersebut yaitu dengan dapat dilihat dari penurunan harga saham, loyalitas konsumen serta lingkungan kerja perusahaan yang tidak kondusif. Ketiga, dorongan etika (ethics driven) mensyaratkan kesadaran dari semua pihak untuk berperilaku, berusaha serta bekerja dengan etika (conformance).

Dorongan etika dapat diumpamakan sebagai kasta tertinggi, karena penerapan good corporate governance bukan lagi karena ada peraturan yang mengharuskan, namun karena pihak-pihak yang terkait sadar bahwa penerapan tersebut memang diperlukan sebagai penjaga amanah yang diberikan serta hanya dengan penerapan good corporate governance sebagai penjaga amanah yang diberikan serta dengan penerapan good corporate governance berkelanjutan iklim usaha dapat berkembang dengan sehat. Idealnya penerapan good corporate governance memerlukan sedikitnya ketiga hal tersebut secara bersama-sama (Daniri, 2005)

Salah satu pilar yang mendukung tegaknya good corporate governance adalah adanya budaya unggul yaitu dengan focus pada sisi terdalam perusahaan yaitu dengan membangun dan memiliki budaya unggul. Perusahaan-perusahaan yang unggul adalah perusahaan yang memiliki keunggulan manajemen dan kepemimpinan yang unggul dan berhasil mempertahankan keunggulan tersebut (Moeljono, 2005). Faktor "berhasil mempertahankan" merupakan faktor "nilai" terutama nilai budaya.

Budaya unggul dalam perusahaan seperti budaya disiplin. Sedangkan disiplin dapat dilihat dalam tiga hal yaitu : orang-orang yang disiplin, pikiran yang disiplin dan tindakan yang disiplin. Budaya perusahaan meliputi niliai-nilai dasar yang dimiliki perusahaan, motto perushaan, hal apa yang dilakukan seseorang untuk sukses di perusahaan, karyawan atau pimpinan seperti apa dihormati, tindakan apa yang dianggap hal yang terpuji, kesalahan seperti apa yang tidak dapat dimaafkan oleh perusahaan, mitos, simbol dan upacara apa yang mengungkapkan ciri perusahaan yang paling esensial dan peraturanperaturan pokok apa yang harus dipatuhi oleh semua anggota perusahaan (Purnomo, 2005). 


\section{PENUTUP}

Dengan diterapkan good corporate governance secara konsisten akan berdampak positif bagi bank-bank syariah, karena dalam good corporate governance meliputi hal-hal yang sejalan dengan syariah Islam seperti transparansi, independensi, akuntabilitas dan responsibilitas. Maka dari itu good corporate governance akan menciptakan budaya unggul perusahaan, sehingga dengan budaya unggul tersebut apa yang menjadi tujuan perusahaan akan lebih mudah tercapai. Di samping itu budaya unggul akan membentuk suasana kerja yang dinamis dan profesional.

Good corporate governance juga akan memperkuat sistem sehingga fungsi kepemimpinan dan organisasi akan membentuk suatu nilai. Apabila hal itu akan berlanjut secara berkesinambungan maka akan memberikan kontribusi positif yang menguntungkan bagi perusahaan atau perbankan syariah. Kepercayaan juga akan didapat baik dari internal maupun eksternal perusahaan.

\section{DAFTAR PUSTAKA}

Brigham \& Houston, 2006, Fundamentals of Financials Managemen (Dasar-Dasar Manajemen Keuangan), Jakarta: Salemba Empat.

Endraswati, Hikmah, Loyalitas Nasabah Bank Syariah dan Good Corporate
Governance dalam Jurnal EKBISI UIN Sunan Kalijaga Yogyakarta Vol. 1 No. 2 Juni 2007

Kaihatu, Thomas S. Good Corporate Governance dan Penerapannya di Indonesia JURNAL MANAJEMEN DAN KEWIRAUSAHAAN, VOL.8, NO. 1 , MARET 2006: 1-9

Moeljono, Djokosantoso, Good Corporate Culture Governance Sebagai Inti Dari Good Corporate Governance, Jakarta : Elex Media Komputindo, 2005.

Muhammad, Manajemen Bank Syariah, 2004, Yogyakarta, UPP, YKPN.

Peraturan Bank Indonesia No. 11/33/PBI/2009 tentang Pelaksanaan Good Corporate Governance Bagi Bank Umum Syariah dan Unit Usaha Syariah.

Purnomo, Andiral, Disiplin Eksekusi, Warta Ekonomi, 2005, Jakarta

Retno, Reny Dyah, Pengaruh Good Corporate Governance dan Pengungkapan Corporate Social Responsibility Terhadap Nilai Perusahaan (Studi Empiris Pada Perusahaan Yang Terdaftar Di Bursa Efek Indonesia Periode 2007-2010) Jurnal Nominal / Volume I Nomor I / Tahun 2012

Robbins, Stephen, Perilaku Organisasi : Konsep, Kontroversi dan Aplikasi, Terj. Prenhallindo, Jakarta 2001 